the views of those who find in popular spiritualism a system of thought and practice too crude to attract the more educated believer. As a well-balanced and judicious survey of the Society for Psychical Research past and present, this little book is to be highly commended. It shows the Society in what may be thought by some to be its best role, namely, a nucleus around which are gathered research workers of varied opinions who can use its platform for their results and get expert help and guidance when required for improving the quality of their work and assessing its value. The Society has had a long and distinguished career, and much of its published material is of the greatest value both to the psychologist and to the student of evidence and the value of testimony. To those who wish to inform themselves more fully of these aspects of the Society's work, no better introduction could have been devised than this little book.

\section{Learning and Industry}

A VALUABLE means of bringing about active co-operation between industry and the universities has recently been shown by the United Steel Companies, Ltd. At the invitation of the chairman, Sir Walter Benton Jones, fourteen mechanical and production engineering professors from British universities spent four days, beginning on April 12, in visiting the branches of the United Steel Companies at Sheffield, Scunthorpe and Stocksbridge, and in joint discussion both at the various works and at the Sheffield headquarters. Among the topics discussed were the design of Siemens open-hearth furnaces, the fuel balance of an integrated steelworks, and, led by Sir Charles Goodeve, director of the British Iron and Steel Research Association, some general research problems of the iron and steel industry. It was clear from the discussions that the research staff of the United Steel Companies were grateful for suggestions thrown out by the professors, while the latter were appreciative of the new problems put to them and which, in some cases, could usefully be followed up by them and their research staffs. By arranging this tour the United Steel Companies have shown a way in which industry and scholarship can work together for their mutual help and the well-being of British economy.

\section{Australia and New Zealand Association for the Advancement of Science}

THE report of the twenty-fifth meeting of the Australia and New Zealand Association for the Advancement of Science, held at Adelaide during August 1946, with its list of officers and research committees, balance sheet, constitution and by-laws, sectional transactions and reports of research committees, is something more than a useful reference work for the Association. In addition to Dr. P. Marshall's presidential address on "The Permanent Pacific" and Dr. Adrien Albert's Liversidge Centenary Lecture on "What can Chemistry Contribute to the Mastery of Disease ?", it includes the addresses of the sectional presidents. Some of the latter, such as those of Dr. Ian W. Wark to the Chemistry Section on "Australian Research on the Theory of Flotation", Dr. W. M. Bryan on "The Geological Approach to the Study of Soils", Dr. J. Pearson on "Some Problems of Marsupial Phylogeny", Dr. R. Wilson on "Facts and Fancies of Productivity", Dr. H. W. Bennetts on "The Pathological Approach to Problems of Animal Disease", and Prof. E. Ashby's "Survey of Botany in the Soviet Union" appear to be of notable scientific interest and deserve the wider audience that they can now reach. Among other addresses included are those of R. Lemberg on "New Aspects of the Theory" of Function of Respiratory (Hæmatin) Enzymes", A. Gottschalk on "Some Aspects of the Relationship between Chemical Structure and Enzyme Specificity", and of A. T. S. Sissons on "The Widening Front of Pharmaceutical Science".

\section{Archæology in South Africa}

The report for 1946-47 of the Archæological Survey of the Union of South Africa has been published (Johannesburg). The most interesting piece of information therein is that the Little Caledon River has apparently cut its bed down some $300 \mathrm{ft}$. through Beaufort Sandstone since the occupation of the upper part of the valley by early Stellenbosch man. Sandstone, of course, is not such a hard material as basalt; nevertheless, a long period of time must be postulated since early man lived in those regions. Dr. van Riet Lowe has published a note in the South African Archoological Bulletin, 2, Pt. 8 (1947) on some interesting tanged and winged arrow-heads. This type of tool has not been found heretofore in the Union. Dr. van Riet Lowe assigns them, no doubt rightly, to a Neolithic stage of development. $\mathrm{He}$ does mention, incidentally, the discovery of somewhat similar arrow-heads in a so-called Solutrean milieu in eastern Spain; but it may be premature to assign Dr. Pericot's finds definitely to the European Solutrean culture. Spanish prehistory south of the northerm mountain ranges looks mainly to North Africa for its connexions. Maybe the word Aterian will have to be substituted for Solutrean eventually. But the occurrence of tanged and winged arrowheads in the South African Neolithic is indeed an interesting addition to knowledge.

\section{Identification of Important Indian Timbers}

IF any one factor could be picked out as justifying forestry research in the tropical and sub-tropical forest containing many timber species growing in mixture, it would consist in some popular means of identifying the various kinds. This problem first presented itself in India during the First World War, when many species of timber, practically previously unmarketable, came into use. The demand on the Indian forests was far greater in the Second World War. For the use of the Army, six leaflets entitled "How to Identify Timbers" were issued from Dehra Dun. These have now been collected together into Indian Forest Record (Utilisation), Vol. 3, No. 7, by the wood technologist of the Forest Research Institute, and keys and photomicrographs of the timbers that are commercially available in the different military zones of inspection have been added. The photomicrographs, on which 114 timbers are shown in 57 plates, are very clear. The writer says they will be as useful to the commercial trader as to the military authorities; he might have added also to the district forest officer and his staff in part $s$ of the country where new timbers, previously unmarketable, are now commercially salable.

\section{The Food of Humming-Birds}

AN excellent monograph on the feeding and related behaviour of humming-birds (with special reference to the black-chin, Archilocus alexandri) was prepared by Frank Bené before his death in 1943 
and has now been published as a Memoir of the Boston Society of Natural History (9, No. 3 ; October 1946). The work was carried out during 1939-42 in Phoenix and other localities of Arizona, and, because of its docility, its fondness for commercial sweets, and its regularity in returning to feed from artificial sources of food, the humming-bird proved to be an amenable subject for observation and experiment. The black-chinned humming-bird is strongly migratory, and its arrival on the spring breeding ground coincides with the flowering of its food plants. The sexes select and maintain isolated territories and meet on a neutral ground, the lex. Feeding habits of the humming-bird support Howard's theory of the nutritive function of territory. The monograph also describes the feeding routine, type and quantity of food consumed and the three feeding techniquesflower-probing, hovering-pecking and fly-catching. The Memoir contains twelve black-and-white plates which should delight all bird lovers.

\section{The Brotherton Collection, Leeds}

THE eleventh and twelfth reports of the Brotherton Collection Committee, University of Leeds, covering the sessions 1945-46 and 1946-47, respectively, estimate the contents of the Collection on June 30 , 1947 , as 22,700 books, 15,413 pamphlets, 473 manuscripts, 4,105 deeds, 31,158 letters and 25 maps; the increase on June 30,1946 , being 61 books, 65 pamphlets and 32 letters. Undergraduates continued to use the Collection for special studies, particularly in English literature, and the return to more normal conditions was shown by an increasing number of inquiries from abroad. Many of the visits to the Collection during 1945-46 were specially arranged in connexion with an exhibition of the collection of English county atlases and road maps presented to the University by Dr. Harold Whitaker. The practice of holding exhibitions of the Collection's treasures is to be revived, and during 1946-47 an exhibition of bindings was arranged in connexion with the Leeds Conference of the Intermational Society of Leather Trades Chemists. The re-cataloguing of books in the English literature section continued and 2,601 slips were added to the Supplementary Catalogue in 194546 and 880 in 1946-47. Ten books and pamphlets were presented in 1945-46 and 101 purchased, the corresponding figures in 1946-47 being 74 and 52 as well as 52 autograph letters presented.

\section{Linnean Society of London: Anniversary Meeting}

Ar the anniversary meeting of the Linnean Society of London held on May 24, the Linnean Gold Medal was presented to Dr. Agnes Arber, and Trail Awards and Medals were presented to Dr. Honor Bridget Fell and Dr. Cyril Dean Darlington. The following were elected officers for the session 1948-49: President: Prof. G. R. de Beer ; Treasurer : Colonel F. C. Stern ; Secretaries : Dr. B. Barnes (Botany), Dr. A. Tindell Hopwood (Zoology). The new members of council were Mr. James M. Fisher, Mr. N. B. Kinnear, Prof. W. H. Pearsall, Dr. W. R. Philipson and Mr. N. Y. Sandwith.

\section{South Eastern Union of Scientific Societies}

THE fifty-second annual congress of the SouthEastern Union of Scientific Societies will be held at Great Yarmouth during June 14-19, under the presidency of Mrs. Jacquetta Hawkes, who will speak on "Archæology and the Present". The meetings will be held in the Town Hall. The sectional presidents and the titles of their addresses are: H. J. Howard (Botanical Section), "The Mycetozoa of Sand-dunes and Marshland"; Lieut.-Colonel S. E. Glendenning (Archæological Section), "Local Materials and Craftsmanship in Norfolk Buildings"; C. D. Ovey (Geological Section), "Foraminifera in Stratigraphy with Special Reference to the Ecology of Living Forms"; Major Maxwell Knight (Zoological Section), "The Study of Bird Pellets as a Subject of Interest and Instruction to Amateur Naturalists". On June 17 there will be a "Young Naturalists' Evening", at which Nature films will be shown and a 'brains trust' held. A discussion on the functions and organisation of local societies, to be opened by G. E. W. Gosnell, will be held on June 18. The local secretary of the meeting is Mr. P. E. Rumbelow, 27 Rodney Road, Great Yarmouth; the honorary general secretary of the Union is Mr. F. J. Epps, 78 Dunwich Road, Bexleyheath, Kent.

\section{Population and World Resources in Relation to the Family}

AN International Congress on "Population and World Resources in Relation to the Family" will be held at Cheltenham during August 23-28. The programme for the Congress, which has been organised by the Family Planning Association of Great Britain, includes general sessions devoted to the following topics: world resources; essential standards of living; migration as a factor in the adjustment of national populations; sociological implications of family limitation in various typical countries; birth control as a factor in the adjustment of national population; ethical and medical advantages of planned family limitation; current and future research in problems of fertility, infertility, sex and marriage; agencies for the dissemination of knowledge and propaganda. Further particulars can be obtained from the Cheltenham Congress Organiser, 37 Park Street, London, W.1.

\section{Announcements}

Sir JAmes Chadwick, honorary fellow of Gonville and Caius College, Cambridge, and Lyon Jones pro. fessor of physics in the University of Liverpool, has been pre-elected Master of the College to succeed Mr. J. F. Cameron, who retires on September 30 .

THE Association of British Science Writers is holding its first forum discussion meeting on "Science and the Press" on June 9 at 7.30 p.m. at the Society for Visiting Scientists, 5 Old Burlington Street, London, W.1. The meeting will be open to the public and admission is free.

A RESEARCH scholarship of the value of $£ 400$ per annum and tenable for two years has been offered by the Aluminium Development Association to encourage and facilitate research in the application of light alloys to ship construction. The scholarship will be administered by a Committee of the Institution of Naval Architects and it is hoped to make the award in September. Full particulars of entry, which closes on July 31, can be obtained from the Secretary, Institution of Naval Architects, 10 Upper Belgrave Street, London, S.W.I.

Erratum. In the communication entitled "Transmission of Bactericidal Radiation through Glass" (Nature, May 29, p. 856), the lettering of the two curves should be interchanged. 